\title{
ANALISA DAN PERANCANGAN SISTEM INFORMASI SEKOLAH BERBASIS WEBSITE UNTUK PENYAMPAIAN INFORMASI SEKOLAH DAN MEDIA PROMOSI KEPADA MASYARAKAT
}

\author{
Yudie Irawan \\ Fakultas Teknik, Program Studi Sistem Informasi \\ Universitas Muria Kudus \\ Email: yudie.irawan@umk.ac.id \\ Nanik Susanti \\ Fakultas Teknik, Program Studi Sistem Informasi \\ Universitas Muria Kudus \\ Email: nanik.susanti@umk.ac.id \\ Wiwit Agus Triyanto \\ Fakultas Teknik, Program Studi Sistem Informasi \\ Universitas Muria Kudus \\ Email: at.wiwit@umk.ac.id
}

\begin{abstract}
ABSTRAK
Saat ini sekolah berusaha menjadi institusi pendidikan yang mampu melayani masyarakat dengan baik, terutama dalam hal penyampaian informasi kepada masyarakat. Selama ini Pemberitahuan tentang informasi sekolah masih dilakukan secara manual, kebanyakan informasi terbaru masih ditempel dipapan pengumuman, melalui speaker yang dipasang tiap kelas, surat selebaran yang dibagikan kepada siswa dan masih menggunakan media informasi seperti spanduk dan pamflet sebagai media promosi kepada masyarakat. Oleh karena itu, pada penelitian ini dilakukan analisa kebutuhan untuk menghasilkan website sekolah dengan menggunakan pemodelan UML (Unified Markup Language). Pemanfaatan website dalam pengembangan kompetensi dan kualitas sekolah merupakan hal yang tepat dikarenakan website adalah media yang sangat interaktif dan dinamis untuk menambah wawasan sekaligus untuk eksistensi diri. Implementasi sistem informasi sekolah berbasis website dapat diakses kapan saja dan dimana saja melalui internet. Website sekolah dapat mengatasi permasalahan dalam penyampaian informasi serta proses promosi sekolah yang selama ini masih dilakukan secara manual.
\end{abstract}

Kata kunci: Sistem, Informasi, Sekolah, Website, $U M L$.

\begin{abstract}
Currently the school seeks an educational institution that is able to serve the community well, especially in terms of delivering information to the public. During this Notice of school information is still done manually, mostly still taped to the latest information dipapan announcement, through the speaker mounted each class, pamphlets were distributed to students and still using information media such as banners and flyers as a promotional media to the public. Therefore, in this study conducted a needs assessment to produce the school website by using modeling UML (Unified Markup Language). Utilization of the website in the development of competence and quality of the school is the right thing because the website is very interactive media and dynamic to broaden as well as to the existence of self. Implementation of information systems based school website can be accessed anytime and anywhere via the internet. Website school can overcome the problems in the delivery of information and the promotion of school, which is still done manually.
\end{abstract}

Keywords: Sistem, Information, School, UML.

\section{PENDAHULUAN}

Perkembangan teknologi informasi dan komunikasi khususnya internet melahirkan sebuah media baru yaitu website, yang semakin lama semakin berkembang dan dimanfaatkan dalam setiap bidang kehidupan, baik secara pribadi maupun institusi. Demikian halnya dalam dunia pendidikan, website merupakan sarana penyampaian informasi secara online yang memiliki fasilitas dasar internet yang 
mampu menembus batasan ruang dan waktu. Sementara ditengah pesatnya perkembangan dunia yang penuh persaingan, informasi merupakan bagian yang sangat penting dari komponen pendidikan. Penyampaian informasi yang cepat, tepat dan mudah akan sangat mendukung kegiatan pendidikan di instansi-instansi terkait.

Sekolah merupakan bangunan atau lembaga untuk belajar dan mengajar, serta tempat menerima dan memberi pelajaran. Sebagaimana yang telah kita ketahui bahwa sekolah merupakan salah satu tempat bagi para siswa untuk menuntut ilmu. Hingga sekarang sekolah masih dipercaya oleh sebagian besar anggota masyarakat sebagai salah satu tempat untuk belajar, berlatih kecakapan, menyerap pendidikan atau tempat proses mendewasakan anak.

Saat ini sekolah berusaha menjadi institusi pendidikan yang mampu melayani masyarakat dengan baik, terutama dalam hal penyampaian informasi kepada masyarakat. Selama ini Pemberitahuan tentang informasi sekolah masih dilakukan secara manual, Kebanyakan informasi terbaru masih ditempel dipapan pengumuman, melalui speaker yang dipasang tiap kelas, surat selebaran yang dibagikan kepada siswa dan masih menggunakan media informasi seperti sepanduk dan pamflet sebagai media promosi kepada masyarakat.

Mengingat pentingnya informasi perlu disadari oleh pelaku-pelaku pendidikan dalam hal ini tenaga pendidik dan kependidikan senantiasa berupaya mengupdate kompetensi mereka. Salah satu alternatif dalam pengembangan kompetensi dan kualitas diri adalah dengan pemanfaatan website, karena dianggap media yang sangat interaktif, media yang sangat dinamis untuk menambah wawasan sekaligus untuk eksistensi diri.

Berdasarkan hal tersebut, dalam penelitian ini dirancanglah sistem informasi sekolah berbasis website sehingga diharapkan dapat membantu pihak sekolah dalam menyampaikan berbagai informasi kepada Guru, Karyawan, Siswa dan Masyarakat Umum.

\section{TINJAUAN PUSTAKA}

Riyadi, A.S. dkk mengemukakan dalam penelitiannya bahwa penyampaian informasi mengenai sekolah dengan sistem informasi berbasis website dapat memberikan jangkauan informasi yang jauh lebih luas dibandingkan dengan cara manual, sehingga mempermudah masyarakat untuk mencari informasi tentang sekolah tersebut. Selain itu, sistem informasi berbasis website dapat menghilangkan batasan ruang, waktu dan jarak bagi para santriwan/santriwati untuk melakukan aktifitas akademik [1].

Kristanto, Y. dan Triono, R.A dalam penelitiannya menghasilkan web profil SDN Laweyan Surakarta yang digunakan sebagai media informasi yang mudah dan efektif yang dapat diakses dimana saja dan kapan saja secara online. Semua informasi yang berhubungan dengan SDN Laweyan Surakarta dapat lebih mudah didapatkan melalui website, sehingga dapat membantu meningkatkan mutu pendidikan SDN Laweyan Surakarta [2].

\section{METODOLOGI PENELITIAN}

\subsection{Metode Pengumpulan Data}

Metode pengumpulan data yang digunakan dalam penelitian ini adalah sebagai berikut:

a. Metode Observasi, pengamatan yang dilakukan secara sengaja dan sistematis untuk kemudian dilakukan pencatatan dengan menggunakan dan mempelajari praktek-praktek pelaksanaan di tempat penelitian meliputi proses penyampaian informasi sekolah serta proses promosi sekolah.

b. Metode Kepustakaan, untuk memperluas cakrawala pandang, maka perlu membaca buku yang sesuai dengan permasalahan yang ada, sebagai bahan pertimbangan untuk mendapatkan data sekunder yang mengacu pada literatur, buku, diktat, catatan yang dapat menunjang penyusunan penelitian tentang website sekolah.

c. Metode Wawancara, untuk mendapatkan masukan berkenaan dengan sistem yang dibuat maka dilakukan wawancara yang berkaitan dengan permasalahan yang terjadi dalam penyampaian informasi sekolah.

d. Metode Dokumentasi, metode ini digunakan untuk mengetahui proses-proses penyampaian informasi sekolah yang pernah dilakukan.

\subsection{Analisa Kebutuhan}

Dalam membangun website sekolah dibutuhkan data, diantaranya:

a. Data Siswa

b. Data Guru

c. Data Pelajaran 
d. Data Info Sekolah

e. Data Galeri

Berdasarkan data-data tersebut, diharapkan dapat menghasilkan sebuah website sekolah yang dapat mengelola beberapa hal berikut:

a. Kelola Data Kelas

b. Kelola Data Silabus

c. Kelola Data Materi Ajar

d. Kelola Data Materi Uji

e. Kelola Data Prestasi Siswa

f. Kelola Data Prestasi Sekolah

g. Kelola Data Agenda

h. Kelola Data Artikel

i. Kelola Data Berita

j. Kelola Data Buku Tamu

k. Kelola Data Jajak Pendapat

\subsection{Perancangan Sistem}

Dalam perancangan sistem dilakukan pemodelan proses untuk mengilustrasikan aktivitas-aktivitas yang dikerjakan dan bagaimana data tersebut berpindah diantara aktivitas-aktivitas tersebut. Cara untuk merepresentasikan proses model dengan menggunakan UML (Unified Modeling Language). UML (Unified Modeling Language) merupakan sistem arsitektur yang bekerja dengan Object Oriented Arcitechture Design (OOAD) dengan satu bahasa yang konsisten untuk menentukan, visualisasi, mengkontruksi, dan mendokumentasikan artifact yang terdapat dalam sistem software [3].

\section{HASIL DAN PEMBAHASAN}

\subsection{Diagram Hierarki Menu}

Pada gambar 1 menggambarkan diagram hierarki sistem informasi sekolah berbasis website yang terdiri dari beberapa menu utama, yaitu: Home, Profil, Organisasi, Kesiswaan, Galeri, Download Pustaka, Buku Tamu.

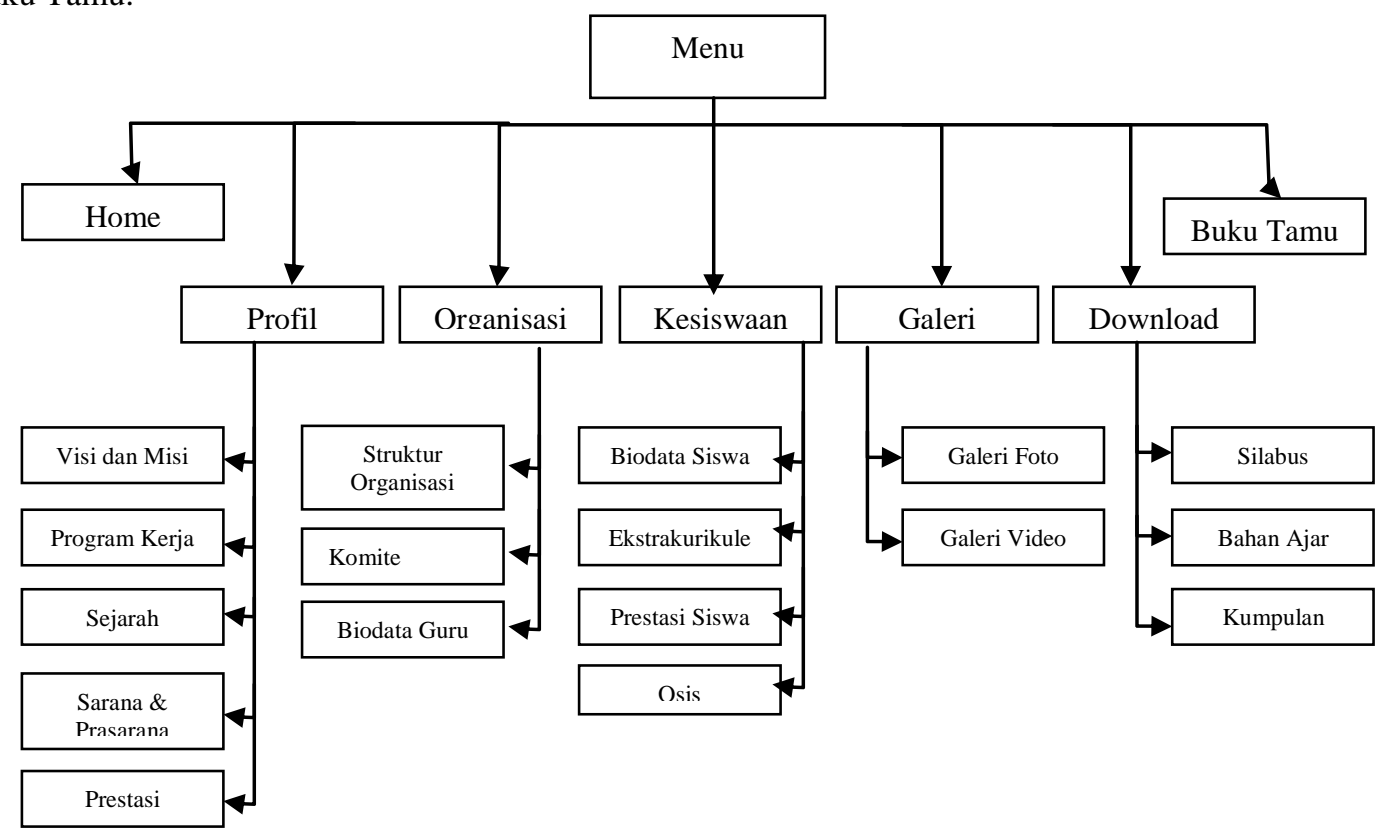

Gambar 1. Diagram Hierarki Menu Sistem Informasi Sekolah Berbasis Website

\subsection{Use Case Diagram}

Pada Gambar 2 menggambarkan use case diagram untuk sistem informasi sekolah berbasis website yang memiliki 1 aktor, yaitu: Admin. Admin dapat mengelola menu website, mengelola admin, mengelola banner, mengelola agenda, mengelola artikel, mengelola berita, mengelola profil, mengelola buku tamu, mengelola info sekolah, mengelola kelas, mengelola guru, mengelola siswa, mengelola materi 
uji, mengelola materi ajar, mengelola silabus, mengelola pelajaran, mengelola prestasi siswa, mengelola prestasi sekolah, mengelola galeri, dan mengelola jajak pendapat.

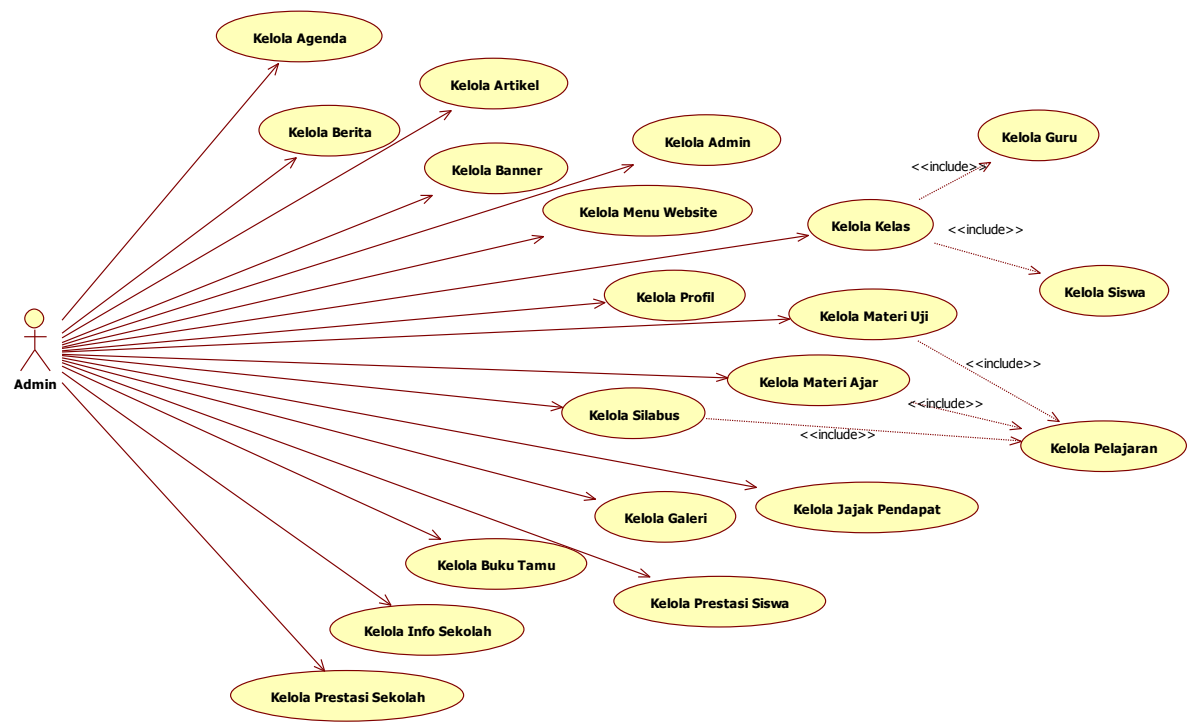

Gambar 2. Use Case Diagram Sistem Informasi Sekolah Berbasis Website

\subsection{Class Diagram}

Pada Gambar 3 menggambarkan class diagram untuk sistem informasi sekolah berbasis website. Class diagram sistem informasi sekolah berbasis website terdiri dari beberapa class, yaitu: class admin, class menu_website, class banner, class agenda, class artikel, class berita, class profil, class buku_tamu, class info_sekolah, class prestasi_sekolah, class galeri, class prestasi_sekolah, class jajak_pendapat, class silabus, class materi_ajar, class materi_uji, class pelajaran, class kelas, class guru, class siswa.

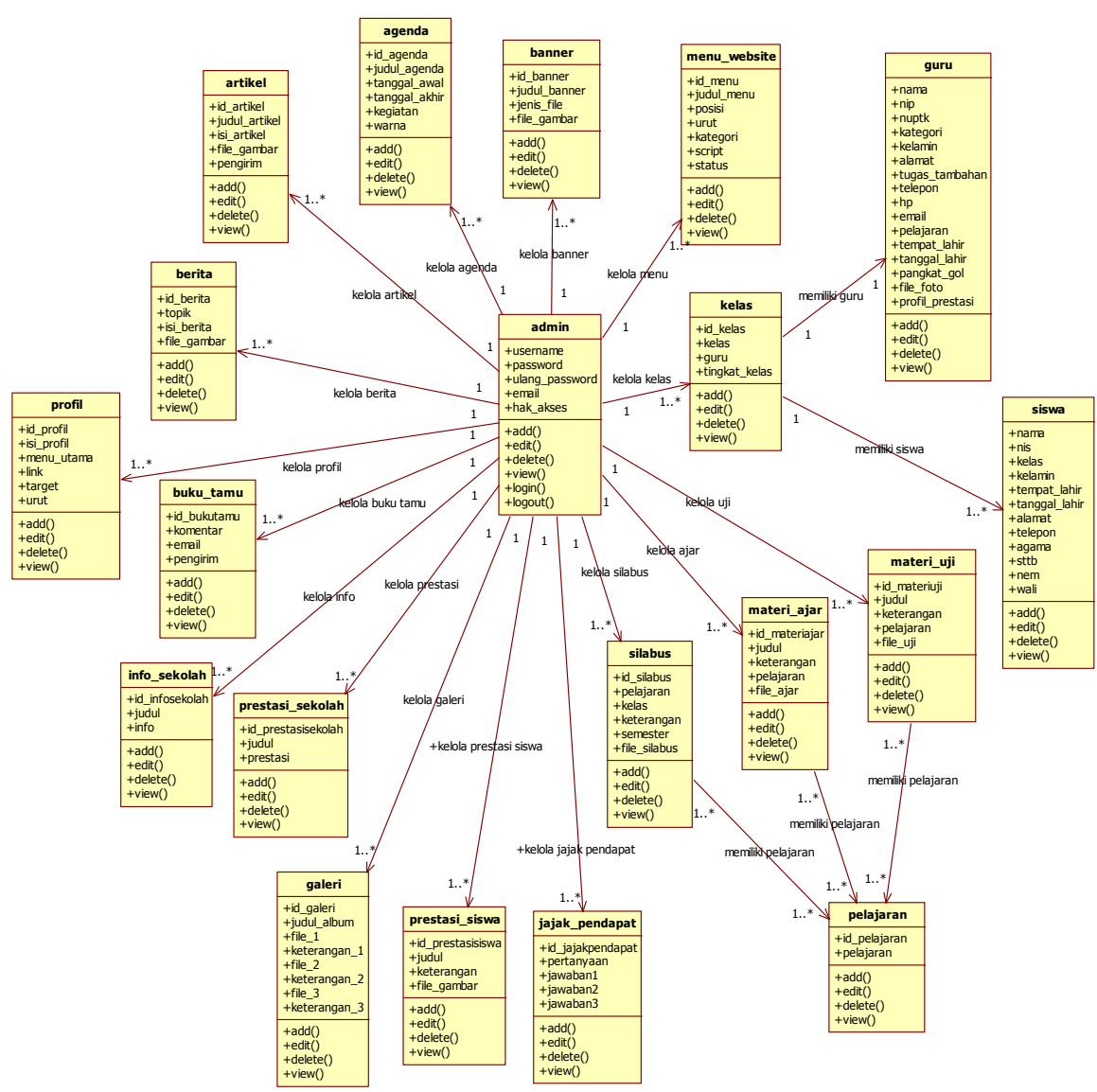

Gambar 3. Class Diagram Sistem Informasi Sekolah Berbasis Website 


\subsection{Implementasi Sistem}

Implementasi sistem informasi sekolah berbasis website dapat diakses melalui internet dengan menggunakan berbagai macam web browser (Mozilla firefox, Internet Explorer, Opera, Google Chrome). Berikut beberapa tampilan sistem informasi sekolah berbasis website:

a. Halaman Utama

Halaman utama menampilkan website dengan warna tema hijau dan terbagi menjadi 3 kolom. Pada bagian atas website terdapat banner dan menu. Pada bagian kiri website terdapat kumpulan link, jajak pendapat, statistik dan agenda. Pada bagian tengah website terdapat berita terbaru, info penerimaan peserta didik baru, sambutan kepala sekolah dan artikel terbaru. Pada bagian kanan website terdapat pencarian, info sekolah, galeri dan materi ajar. Untuk lebih jelasnya, halaman utama pada sistem informasi sekolah berbasis website dapat dilihat pada gambar 4 .

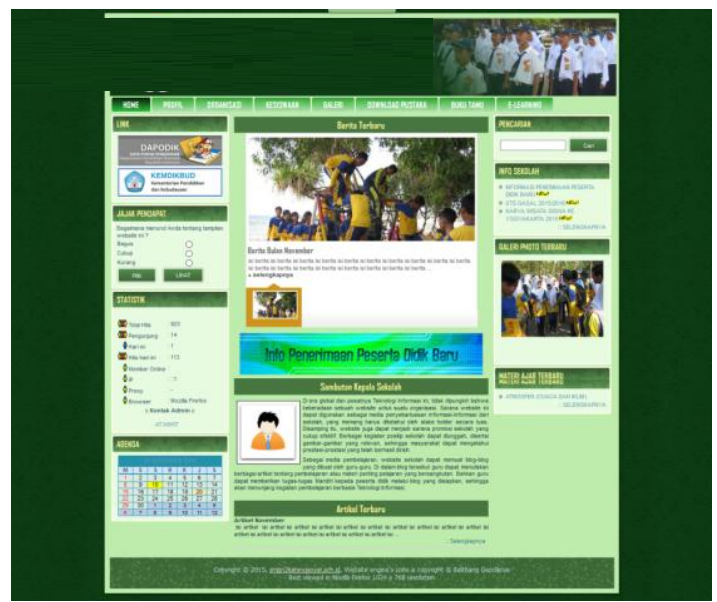

\section{Gambar 4. Halaman utama sistem informasi sekolah berbasis website}

b. Halaman Login

Halaman login digunakan untuk masuk ke dalam website sebagai administrator. Agar login berhasil, username dan password harus dimasukkan dengan benar. Untuk lebih jelasnya, halaman login admin pada sistem informasi sekolah berbasis website dapat dilihat pada gambar 5 .

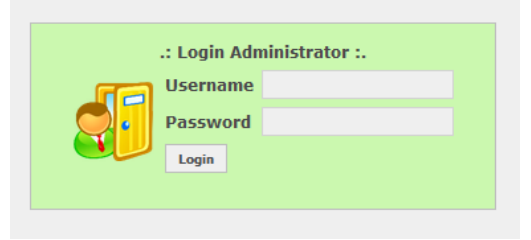

\section{Gambar 5. Halaman login admin}

c. Halaman input data siswa

Halaman input data siswa digunakan untuk menambah pengisian data siswa. Beberapa data siswa yang harus di isi antara lain: nama, nis, kelas, kelamin, tempat lahir, tanggal lahir, alamat, telepon, agama, sttb, nem dan wali. Untuk lebih jelasnya, halaman input data siswa pada sistem informasi sekolah berbasis website dapat dilihat pada gambar 6 .

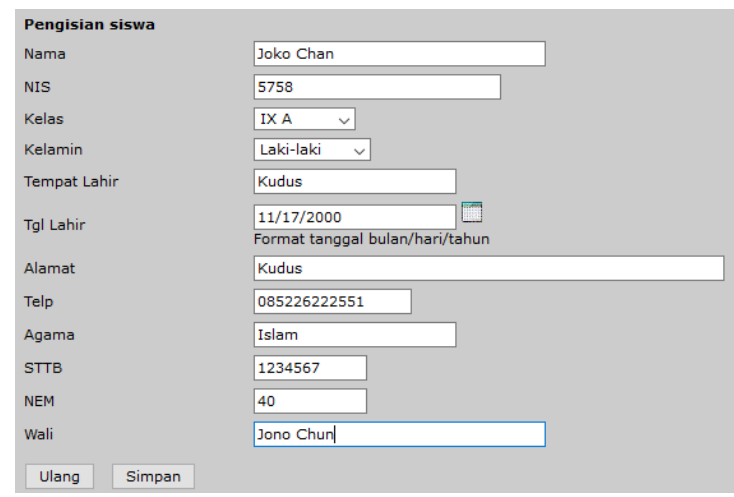

Gambar 6. Halaman input data siswa 
d. Halaman input artikel

Halaman input artikel digunakan untuk menambah artikel atau tulisan yang akan ditampilkan pada website. Beberapa pengisian data yang harus dilengkapi antara lain: judul, isi, file gambar dan pengirim. Untuk lebih jelasnya, halaman input artikel pada sistem informasi sekolah berbasis website dapat dilihat pada gambar 7 .

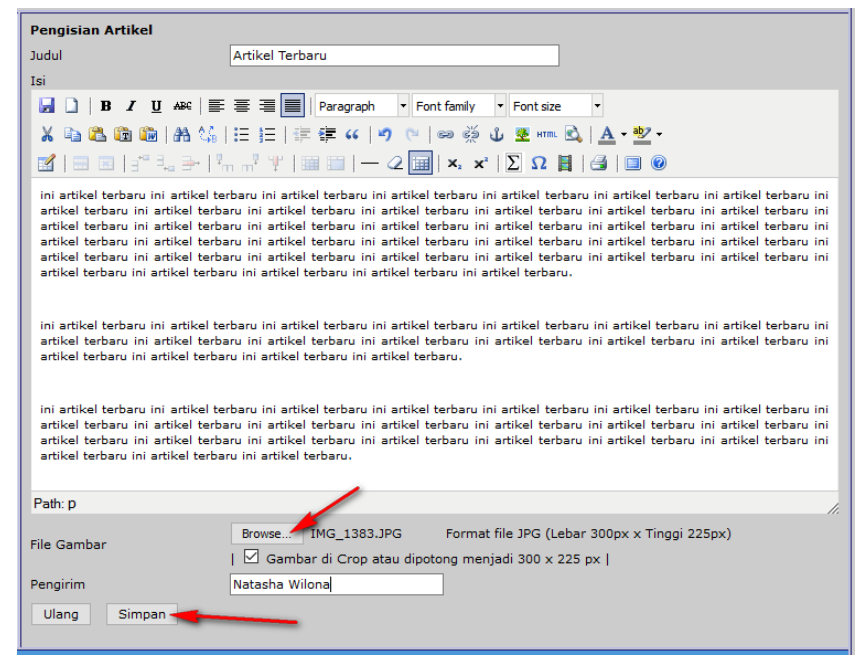

Gambar 7. Halaman input artikel

e. Halaman input silabus

Halaman input silabus digunakan untuk silabus dari pelajaran yang daiajarkan pada sekolah. Beberapa data silabus yang harus dilengkapi antara lain: pelajaran, kelas, keterangan, semester, file silabus. Untuk lebih jelasnya, halaman input silabus pada sistem informasi sekolah berbasis website dapat dilihat pada gambar 8 .

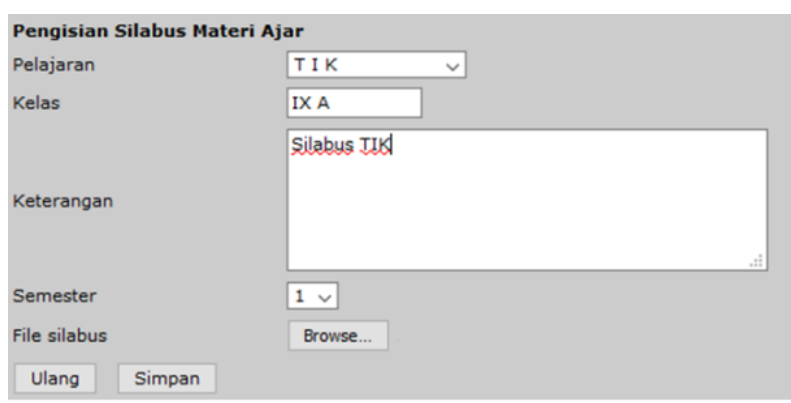

Gambar 8. Halaman input silabus

\section{KESIMPULAN}

Dari hasil penelitian yang telah dilakukan dapat disimpulkan sebagai berikut:

a. Pemanfaatan website dalam pengembangan kompetensi dan kualitas sekolah merupakan hal yang tepat dikarenakan website adalah media yang sangat interaktif dan dinamis untuk menambah wawasan sekaligus untuk eksistensi diri.

b. Implementasi sistem informasi sekolah berbasis website dapat diakses kapan saja dan dimana saja melalui internet.

c. Website sekolah dapat mengatasi permasalahan dalam penyampaian informasi serta proses promosi sekolah yang selama ini masih dilakukan secara manual.

\section{DAFTAR PUSTAKA}

[1] Riyadi, A. S., dkk. 2012, "Perancangan Sistem Informasi Berbasis Website Subsistem Guru di Sekolah Pesantren Persatuan Islam 99 Rancabango", Jurnal Algoritma, Vol. 09, No. 40.

[2] Yulis, K., dan Triono, R. A. 2013, "Membangun Web Profil Sekolah Dasar Negeri Laweyan Surakarta", Seminar Riset Unggulan Nasional Informatika dan Komputer FTI UNSA, vol. 2, No. 1.

[3] Suhendar, A. dan Gunadi, H. (2002). Visual Modelling Menggunakan UML dan Rational Rose, Bandung: Informatika. 